\title{
Um olhar de Nietzsche ao século XVII: os subterrâneos da revolução cartesiana
}

\author{
Saulo Krieger*
}

Resumo: Neste artigo pretendemos fazer ver de que modo a "revolução cartesiana" se revelou, para Nietzsche, uma resposta irrefletida a dispositivos inconscientes. A pretensa radicalidade da fundação da filosofia de Descartes e os desdobramentos desta teriam se dado pela intromissão dos seguintes fatores de ação inconsciente: o anseio por acomodação fisiopsicológica por trás do cogito; a moralidade inconsciente a hierarquizar o inteligível como superior ao sensível e ao passional, bem como a fazer pressupor um mundo ordenado, dócil às ideias claras e distintas; um terceiro fator de atuação inconsciente seria as "teias da gramática", que o fizeram se limitar a inverter a primazia entre "eu" e "penso", proporcionando ao pensar, e a seus resultados científicos subsequentes, uma ação de estrangulamento do que até então se tinha pela noção de alma. Esse quadro só fez se agravar até a segunda metade XIX, momento em que Nietzsche depara com a filosofia.

Palavras-chave: Descartes, psicologia, fisiologia, moral, impulsos, alma.

* Doutorando em filosofia pela Unifesp, Brasil. Correio eletrônico: saulokrieger@hotmail.com 
Krieger, S.

A galeria nietzschiana dos hipócritas em filosofia é das mais bem frequentadas. Em número de filósofos e em seu poder de irradiação. Não é de admirar, afinal de contas em filosofia tantas vezes se simularam virtudes para encobrir um conflito, como também tantas vezes se exaltou um maravilhamento diante do mundo para encobrir um desconforto ante suas instabilidades. E tanto se matematizou esse mundo para, por tal abstração, compensar sua pequenez diante dele. Tantas vezes se venerou o etéreo pelas inseguranças do sensível. E tanto se reintroduziu o fator Deus a despeito de se relegar a crença nele. Para Nietzsche a filosofia que metafisicamente hierarquiza o que existe ou o que se pode conhecer é antes, e num estrato mais profundo, a que oculta anseios, conflitos e medos imperscrutáveis. É também a que adorna o que tem por feio ou pouco meritório, por mais que justamente este, em última instância, seja bem o que está a impelir o seu filosofar. Foi assim que já os gregos “ocultavam seu afeto agonal, decorando-se como 'os mais felizes' por meio da virtude" (Nachlass/FP 26 [285], verão - outono de 1884, KSA 11.84). Foi assim que Sócrates ocultou seu pessimismo esgrimindo os círculos aristocráticos de Atenas (Nachlass/FP 26 [285], verão - outono de 1884, KSA 11.84). Foi assim que Leibniz, Kant, Hegel e Schopenhauer hipocritamente ocultaram sua segunda natureza, a alemã (Nachlass/FP 26 [285], verão - outono de 1884, KSA 11.84). E foi assim que, como aqui se verá, nos novos rumos assumidos pela filosofia do século XVII, encarnados sobretudo na revolução cartesiana, muito houve para se ocultar, e isso teria sido feito por movimentos de superficialidade e pressa. No texto que segue, propomos fazer ver o que Nietzsche teria a dizer sobre tais processos de ocultação precisamente no século XVII, século que ele tem por "altivo e aristocrático" (Nachlass/FP, 9 [178], outono de 1887, KSA 12.440). O que teria dissimulado a sua crença e confiança na razão, como num suposto império desta sobre o mundo e sobre as paixões? O século XVII tem aquele que é talvez seu mais emblemático representante em posição muito

224 | Cad. Nietzsche, Guarulhos/Porto Seguro, v.39, n.3, p. 223-245, setembro/dezembro, 2018. 
Um olhar de Nietzsche ao século XVII: os subterrâneos da revolução....

clara e conhecida quanto a esses três aspectos. Sob a confiança e o terreno aparentemente tão seguro do XVII, o olhar psicológico de Nietzsche há de revelar todo um subsolo, tão dissimulado quanto invasivo e determinante.

\section{A superficialidade de Descartes}

Não raro é difícil dizer ou aquilatar o quanto de inconsciência há num ato de hipocrisia. Porque de fato a hipocrisia é solução para um embaraço, podendo ser, como não raro é, total ou parcialmente desapercebida. Da mesma forma, no caso dos tão reflexivos filósofos pode-se igualmente dizer que, sim, sua hipocrisia teve ou tem muito de irreflexão e inconsciência. Nietzsche fala mesmo de equívocos de ordem psicológica, referindo-se a Descartes e Spinoza (cf. Nachlass/ FP 7 [4], final de 1886 - primavera de 1887, KSA 12.259), e a sistemas inteiros tem por "experiências psicológicas mal-interpretadas" (7 [4], Nachlass/FP 7 [4], final de 1886 - primavera de 1887, KSA 12.259). Nesses vários casos, tomando-se o século XVII e precisamente Descartes, haveria a incidência num certo ponto cego. Num ponto que o seu tempo e a sua proveniência não lhe permitiriam identificar ou discernir. E não se trata, em Nietzsche, de propor ou desejar que o que se deu poderia ter se dado de outra maneira: justamente seria bem o contrário, e Nietzsche, em seu século XIX, pode contemplar o modo como aquela filosofia esteve às voltas com seu próprio determinismo, com sua própria inconsciência, ao modo de sina e movimento dos quais se fez refém. Até Nietzsche, excetuando-se os pré-socráticos, ${ }^{1}$ de Sócrates a Schopenhauer se teria uma filosofia prisioneira de seus

1 Os pré-socráticos são aqui excetuados porque para Nietzsche sua experiência filosófica é de outra ordem, calcada em disposições existenciais - os primeiros pensadores são "tipos puros", e não personagens filosóficos híbridos, como se tem a partir de Platão. Pela leitura de A filosofia na época trágica dos gregos e de seus póstumos preparatórios depreende-se que sua filosofia é movida por um pathos afirmativo, lança mão de um pendor intuitivo, como revela o caráter de suas metáforas, sendo também provida de uma feição trágica, já que se expressa ao tempo mesmo em que tem consciência dos limites do conhecimento. 
Krieger, S.

pontos cegos, que incidiam mesmo em certos momentos de fundação, como no XVII. No caso de Descartes, por trás da pedra fundamental sobre a qual se assentou seu filosofar, haveria assim outra pedra num estrato mais profundo, sendo esta, porém, uma pedra de tropeço. Qual teria sido, para Nietzsche, essa pedra de tropeço, a imiscuirse mesmo sob uma certeza matemática, sob o método geométrico? $\mathrm{O}$ que precisamente, e por sob o rigor, está a se confundir, e com qual outro elemento, ou, o que se interpreta mal, ainda que daí se vá haurir prolíficas consequências?

Podemos começar a respondê-lo propondo que se confunde, interpreta-se mal, incorre-se em equívocos de origem sobretudo quando, em seu processo mesmo de intepretação, da autointerpretação dos filósofos, tem-se a atuação determinante de um ou outro fator que não se revela como tal, e não obstante se faz presente, e, mais e pior, faz-se crucial, em atuação prenhe de desdobramentos. $\mathrm{O}$ filósofo se confunde, se equivoca quanto a seus próprios processos tanto mais quanto esse fator, igualmente sem que se o perceba, torna-se mais intenso. Esse fator pode se intensificar a fim de compensar o arrefecimento de outro - por exemplo, o ímpeto moral pode recrudescer e se tornar um objetivo ecumênico universal ao modo de uma desapercebida compensação, a fim de compensar "o fim da crença de que um deus dirige os destinos do mundo" (MA I/HH I 25, KSA 2.46). Em filosofia, como se verá, um ponto de inflexão, uma súbita ou gradual ênfase pode estar a ocultar, em estrato mais profundo, uma relação de compensação e de restauro: a recuperação de um equilíbrio interno, psicológico e, como Nietzsche fará ver, instintual e pulsional.

Quanto ao século XVII, e mais precisamente Descartes, Nietzsche chega a referi-lo por superficial (JGB/BM 191, KSA 5.112) ou por "não radical o suficiente" em seu anseio de certeza (Nachlass/FP 40 [10], agosto - setembro de 1885, KSA 11.632). Parece sugerir que por trás da busca de certeza epistemológica 
Um olhar de Nietzsche ao século XVII: os subterrâneos da revolução....

haveria um "não querer saber", como por trás de uma aparente radicalidade se teria uma busca de acomodação, um contrapeso por um equilíbrio perdido - por uma visão de mundo perdida. De modo mais preciso, o descortinar de uma inteira e nova visão teria suscitado um refúgio na subjetividade, a partir dali mais e mais evidenciada, assim como o desvelamento de um mundo subitamente mais amplo e mais complexo teria demandado o expediente representacional em detrimento do acesso direto às coisas - a pautar as relações com ele. Ora, quanto a essa percepção referente a Descartes não haveria nada de tão novo, a não ser pela observação, por Nietzsche, de que o filósofo francês não teria sido suficientemente radical, de que nele próprio haveria instâncias mais profundas a suscitar a aparente radicalidade e a nela se deter.

Descartes foi fundador por encontrar um novo ponto de partida filosófico, no que fez frente à doutrina Escolástica, tal como era ensinada nos colégios e universidades no início do século XVII, sempre envolta em disputas e em sua própria incapacidade de chegar à verdade sobre as coisas, mantendo-se no âmbito do provável e do incerto. Ao romper com esse contexto, que era de séculos, Descartes fez frente a um mundo que já não podia ser lido pelo viés ontológico que até então se privilegiava: o pensamento cartesiano sacode a poeira aristotélica ao se instaurar no bojo das grandes navegações, das grandes descobertas, que desvelam não apenas um mundo muito mais amplo, mas também muito mais diverso, de outras culturas, a relativizar a europeia, de um mundo em que Deus já não é visto por um prisma único e absoluto - e se ficarmos na Europa, além da versão católica passa a haver os matizes cristãos projetados pela Reforma.

A todo esse quadro Descartes poderia ter reagido à maneira de Montaigne, pouco antes dele, ou seja, com um pensamento afeito à mobilidade, ao desfrute do momento presente, da experiência, por mais que esta sempre o faça deparar com o não idêntico, com o novo. Se assim o fizesse, porém, a seu ver estaria sucumbindo a uma terceira 
Krieger, S.

incerteza a grassar em seu tempo: a ameaça do ceticismo, revivificada pela descoberta de toda uma série de escritos do ceticismo antigo do ceticismo acadêmico e do pirrônico -, protagonizada à excelência pelo próprio Montaigne. Pouco afeito a esse viés, Descartes se pôs a buscar um ponto fixo, que lhe serviria de ponto de partida - um ponto que se mantivesse fixo num mundo móvel, desvelado em sua abertura e amplidão. Como sabemos, esse ponto fixo e de partida, ele o encontrou no cogito, no crivo da coisa pensante, que assim se afirma e se mantém mesmo em sendo a todo tempo enganado. Sabemos também que para sair dessa condição de princípio e mostrar que a res cogitans tem acesso a representações que efetivamente correspondem ao que a res extensa (matéria extensa do mundo) lhe apresenta, Descartes recorre a suas três provas da existência de Deus, e por esse processo estabelece-se, aliado ao cogito, um ponto fixo de máxima abrangência. Esse ponto fixo não poderia estar simplesmente contido no ato de pensar, pois entre todas as perfeições que apresenta encontra-se, herança do medievo e de Santo Anselmo, a existência e o não querer enganar.O liame entre epistemologia e a boa e velha ontologia se faz assim garantido.

\section{Entre moral provisória e moralidade inconsciente}

Resguardadas as imperfeições, que podem bem estar presentes em esquema tão sumário, são essas as linhas gerais do percurso metafísico de Descartes precisamente entre a dúvida metódica e a cadeia de razões. E eis que a um pensador que, como nenhum outro, aparece associado a um começo radical, Nietzsche o acusa de se manter aferrado a "preconceitos morais". Sim, "preconceitos morais (ou razões utilitárias) em favor da certeza e contra a aparência e a incerteza" (Nachlass/FP 40 [10], agosto - setembro de 1885, KSA 11.632), afinal de contas, "por ocasião de seu anseio de ter certeza e de 'eu não quero ser enganado', cumpria se perguntar "por que não?" (Nachlass/FP 40 [10], agosto - setembro de 1885, KSA 11.632). Mas o

228 | Cad. Nietzsche, Guarulhos/Porto Seguro, v.39, n.3, p. 223-245, setembro/dezembro, 2018. 
Um olhar de Nietzsche ao século XVII: os subterrâneos da revolução....

questionamento de Nietzsche, por óbvio, tem mais um efeito retórico, e já ressaltamos que não se trata de nostalgicamente expressar um "como seria" se tivesse ido mais longe. Não poderia ter ido mais longe do que seu tempo permitisse, do que sua fisiologia suportasse. Pois essa fisiologia demandou a Descartes que buscasse fundar a ontologia em outras bases, num viés epistemológico a se ancorar no ser de Deus e no pensamento, alinhavados pela subjetividade. ${ }^{2}$ É fato e sabido que o autor das Meditações não pôde estender esse ímpeto fundador à moral, atendo-se ao que chamou de "moral provisória". 3 Ocorre que para Nietzsche, ao que tudo indica, haveria uma moralidade a atuar de modo mais sub-reptício do que Descartes, em seu tempo, tinha condições de imaginar. Num âmbito mais profundo que o da admissão e da demostração filosóficas, ela seria como que uma segunda natureza, que não admite estar contida em compartimentos ou postergações filosóficas. Em Nietzsche, antes de ser um conjunto de preceitos acerca do que é certo e errado, bom e mau, a moral, mais do que um conjunto de dados acabados, é uma ação interpretativa, e como tal envolve o sujeito que a elabora, suas motivações e as condições de variada ordem pela qual o faz. Isso significa ser a moral um certo sistema de valores que expressam as condições de vida de um certo tipo de homem. Como interpretação, ela é um dispositivo de adaptação às referidas condições de vida, sendo passível de ser reproduzida sem percepção ou esforço, já que sinaliza proteção e defesa desde estratos profundos, que não chegam à consciência. Não raro se manifesta como preferência empedernida pela certeza, contra o incerto e o aparente, que são portadores de ameaças não analisadas nem questionadas. E

2 Sobre a subjetividade não ser propriamente fundamento em Descartes, cf. M. Chauí, 2011, p. 334338, em especial p. 337.

3 Muito além da "moral provisória", que é preciso ter para "viver comodamente", enquanto se sai em busca da verdade das coisas (Discurso do método, III), haveria para Descartes uma moral "definitiva, ideal e possivelmente inatingível, da qual seria preciso encontrar os fundamentos certos, sendo referida na Carta-Prefácio aos Princípios de filosofia (1647) como "a mais elevada e mais perfeita moral", e também "último grau de sabedoria" a pressupor "todo um conhecimento das outras ciências".

Cad. Nietzsche, Guarulhos/Porto Seguro, v.39, n.3, p. 223-245, setembro/dezembro, 2018. 
Krieger, S.

é assim que, irrefletida e indefinidamente, esse ímpeto interpretativo faz estender seus esquemas a outras áreas de elaboração do homem, que não precisavam ou não deveriam estar sujeitas àquele mesmo dispositivo de adaptação. Entre essas outras áreas pode estar, e é frequente, a filosofia, incluindo a filosofia de Descartes. Desse modo, mesmo numa elaboração intelectual que, desperta e reflexiva, se supõe mais consciente que outras atividades humanas, a moral pode inadvertidamente introduzir seus determinantes esquemas. Ela se faz assim como a referida"segunda natureza", tanto mais atuante quanto mais despercebida, mesmo pelos mais rigorosos esforços intelectuais.

Para Nietzsche, no caso de Descartes essa segunda natureza, moral, fê-lo moralizar, como se verá aqui, o seu juízo sobre as percepções sensíveis (Cf. Nachlass/FP 5 [50], verão de 1886 - outono de 1887, KSA 12.201), sobre o que há no mundo, mas sobretudo, e antes disso, sobre a sua busca da verdade. Se acima trouxemos ser a moral um dispositivo de adaptação às condições de vida, e ressaltamos seu efeito rigidificador e passível de ser reproduzido sem percepção ou esforço, tal se dá em nome de compromissos de ordem gregária introjetados e mantidos no homem desde suas camadas mais profundas. Nesses compromissos, mobilizam-se defesas contra movimentos que convulsionam essas camadas, como se tem nas reações instintivas e nas chamadas "paixões". Ao modo de um posicionamento do homem ante circunstâncias e ameaças do que entende ser seu mundo externo, o ordenamento moral finca-lhe raízes profundas e passa a lhe determinar sem que de tal se desse conta. Também os filósofos não se deram conta dessa intromissão à sua revelia, limitando-se a intentar fundamentar esse impulso ordenador ou, de modo puro e simples, deixar-se determinar por ele.

Esse impulso, Descartes o teria fundamentado se suas "verdades claras e distintas" lhe permitissem chegar a uma zona cinzenta como a da moral.Mas a moralidade inconsciente, de enraizamento mais profundo, não demanda qualquer fundamentação, e sim age à revelia.

$230 \mid$ Cad. Nietzsche, Guarulhos/Porto Seguro, v.39, n.3, p. 223-245, setembro/dezembro, 2018. 
Um olhar de Nietzsche ao século XVII: os subterrâneos da revolução....

Isso significa que em Descartes ela esteve a pautá-lo, num efeito quese estendia, como acimaanunciávamos, mesmo às percepções sensíveis. Por ocasião da dúvida metódica e hiperbólica, foi bem de natureza moral "a convicção de que "nada é mais necessário do que a verdade, e em relação a ela tudo o mais é de valor secundário", assim como a generalização "não quero enganar" (FW/GC 344, KSA 3.574). Foi igualmente de natureza moral a generalizada imputação do sensível como algo incerto e enganador. E no mesmo sentido, o irrefletido juízo de Descartes sobre as paixões. Sob seu tratado As paixões da alma (1649) jaz o pressuposto - diga-se, nem um pouco novo em filosofia - de que a razão estaria num nível superior ao das paixões. Moraliza-se a percepção do que parece arredio ou ameaçador a uma ordem instaurada, e aí se tema ordem moral, racional e gregária. Por esse dispositivo moralizante, uma vez sendo o XVII movido por um ímpeto aristocrático e ordenador (cf. Nachlass/FP 9 [178], outono de 1887, KSA 12.240), as "paixões da alma" são sem mais assepticamente apartadas do que é do plano do entendimento; porque é também altivo, orgulhoso (cf. Nachlass/FP 9 [178], outono de 1887, KSA 12.240), são sem mais valorizadas como inferiores ao intelecto e, pelo mesmo motivo, são tidas por algo a que se tem a capacidade de dominar. Assim sendo, bastaria que o entendimento fosse bem conduzido para prevalecer sobre elas.

Além de pré-determiná-lo quanto à questão da verdade, das percepções sensíveis e das paixões, a "segunda natureza", moral, de Descartes, fê-lo irrefletidamente se posicionar quanto ao caráter do que existe no mundo (cf. Nachlass/FP 5 [50], verão de 1886 outono de 1887, KSA 12.201). E de que modo se teria assim de antemão decidido sobre o caráter do existente? E de que modo esse compromisso inconsciente se expressa em sua filosofia? Respondê-lo demanda mais uma vez lembrar que, com o gradual declínio da crença em um deus que dirige os desígnios do mundo, declínio que estava em curso nos séculos XVI e XVII, não apenas a moralidade recrudesceu, 
Krieger, S.

em movimento compensatório (cf. MA I/HH I 25, KSA 2.46), como também, por uma questão inercial, aquela mesma necessidade de recorrer a um fator providencial continua a se projetar feito sombra em paredes de cavernas (cf. FW/GC 108, KSA 3.467). Por mais que a filosofia natural da aurora dos tempos modernos estivesse a substituir crenças e explicações divinas por explicações científicas e, assim, "desencantadas", algo na figura de Deus continuava a sub-repticiamente se afirmar e, sobretudo, a pautar. Por mais que o Deus cristão estivesse cindido quanto ao seu modo de expressão, num estrato mais profundo algo dessa figura mantinha-se uno e vigoroso. E da mesma forma, se a visão geocêntrica era substituída pela heliocêntrica, uma certa necessidade humana não era substituída nem em Descartes nem em seu tempo: a necessidade de centro e de fixidez. O enfraquecimento da crença no Deus que se tinha outrora contrasta com a força funcional e subterrânea dessa necessidade, que age como se no fundo pensasse: "se ora o universo é indefinidamente extenso, como poderei, não obstante, ocupar a posição central, como antes? Lançando mão do cogito, elejo o critério geométrico das 'ideias claras e distintas', e assim de algum modo continuo a estar no centro". E ante o peso de sua elevada aposta na verdade, se a moralidade inconsciente assim proporcionou a dúvida e o isolamento do pensamento em relação ao sensível, as "ideias claras e distintas" são possíveis em razão de uma prévia e irrefletida ordenação do mundo, fruto da mesma moralidade de atuação inconsciente - uma pré-ordenação bem ao gosto da referida aposta na verdade. A dócil ordenação do mundo advém da ponte a religar a res cogitans ao meio sensível: pela referida moralidade, a se antecipar quanto ao que existe no mundo, o próprio pensamento é levado a conceber algo cujas perfeições ele não pode produzir, nem conter por si só, de modo que é levado a atribuí-lo a Deus, como se tem com a prova ontológica de sua existência. A res divina garante a correspondência das ideias claras e distintas com um mundo que assim se lhe faz

232 | Cad. Nietzsche, Guarulhos/Porto Seguro, v.39, n.3, p. 223-245, setembro/dezembro, 2018. 
Um olhar de Nietzsche ao século XVII: os subterrâneos da revolução....

dócil, e com isso a função de Deus torna a se dispor no mesmo leito que antes ocupava. Se já não se têm os adornos e compromissos cristãos, eles são compensados pela moralidade difusa, de atuação sorrateira e disseminada.

Vimos já que o caráter de interpretação atribuído por Nietzsche à moral confere a ela um traço de relatividade, condicionalidade e transitoriedade. Isso por entender que há no fundo uma relação instável, flexível e transitória entre sistemas de valores e as condições de vida que os suscitam. Ocorre que, no curso da história, sempre que se tratou de ajustar uma interpretação moral entre um sistema de valores e um conjunto de condições de vida, os proponentes e seguidores dessa ou daquela moral acreditaram por bem fixar e solidificar o que na verdade é condicionado pela referida relação instável. Num mundo que sempre se mostrou inflexível unicamente no fluxo e na mudança, coube ao homem desde sempre buscar, com vistas a sua autopreservação, regularidades, e assim fixá-las. Daí a relação da moral com a preservação. No cerne da busca de regularidades com vistas à autopreservação, encontra-se a necessidade de fixidez. A autopreservação individual e coletiva acaba se confundindo com a fixação dos próprios códigos e preceitos morais, e já referimos o quanto se replicam em outros domínios.Se Nietzsche rastreia essa necessidade indo às menores estruturas vivas e aos organismos mais rudimentares, aqui não é o caso de como "descer" nessa escala, e sim de "subir" a suas alturas filosóficas, ou seja, de ver que nem mesmo uma filosofia como a de Descartes se fez exceção à regra humana e animal.

\section{Da fixidez à pressa}

A fixidez fazia-se tanto mais necessária no século XVII. Ante um mundo subitamente amplo e plural, que aos olhos do ser humano ainda uma vez demandava ser pacificado e dominado, a busca de Descartes por um plano estável ocasionou-lhe a pressa em encontrar 
Krieger, S.

regularidades, sob a forma de pontos fixos. A pressa em responder a uma ameaça, em interagir com o mundo, por si só é um elemento que faz o filósofo perder o contato com sua própria ação, com a sua própria reflexividade. E tanto mais perde o contato com elas ao se submeter à intromissão de dinâmicas de um tempo que já não era o seu. Quando Descartes chega a seu cogito, acionado num primeiro momento como refúgio e isolamento da dúvida metódica, num segundo como ponto de partida, e num terceiro com as provas da existência de Deus, que lhe asseguram uma "janela para o mundo", sua relação com este já não é direta e imediata como na filosofia antiga. Isso é compreensível, uma vez que entre a Antiguidade e o século XVII o mundo já não era tão próximo, tão familiar, e o ser humano, já não devendo se ver como seu microcosmo e como seu centro, era obrigado a tomar posição, a reconhecer que sua relação com o Universo estaria condicionada por uma perspectiva - por mais que irrefletidamente a tomassepor privilegiada. É nesse contexto que Descartes, na Meditação Terceira, é levado a pôr em exame o valor objetivo das ideias, pelos princípios de causalidade e correspondência, que são condições para reconhecer sua objetividade. A perfazer todo esse cuidado está a noção de ideia - se já não se tem contato direto com a coisa, tem-se o "quadro" ou "imagem" da coisa. Aqui, ainda uma vez, Descartes não saca uma ideia de todo nova, já que o conhecimento como "semelhança" do objeto, isto é, como a representá-lo, ocorrera já aos escolásticos. Mesmo para São Tomás de Aquino representar algo significa conter a semelhança da coisa. Mas o problema em Descartes não está em conceber o conhecimento a se dar pela via da representação. O problema está em fazê-lo ao tempo mesmo em que, antes, inaugura o cogito como sua primeira certeza - que assim, aliás, já não é diretamente "verdade". O problema em Descartes é, seguindo essa tônica, passar a pretender um acesso direto a seus conteúdo mentais e, em meio a eles, ter acesso a uma "certeza imediata", a um "conhecimento absoluto" (JGB/BM 16, KSA 5.29). Não obstante ter

234 | Cad. Nietzsche, Guarulhos/Porto Seguro, v.39, n.3, p. 223-245, setembro/dezembro, 2018. 
Um olhar de Nietzsche ao século XVII: os subterrâneos da revolução....

se reconhecido como perspectiva subjetiva, e não obstante conceber a ideia como representação da coisa, o filósofo francês ignorou essas próprias mediações por ele desveladas e entendeu esse conhecimento como imediato, absoluto, indecomponível. Nesse sentido, por uma questão de irrefletida pressa, Descartes esteve longe de analisar o que se encontra na proposição “eu penso", incorrendo, segundo Nietzsche, em "uma série de afirmações temerárias, cuja fundamentação é difícil, talvez impossível" (JGB/BM, 16, KSA 5.29). Pela pressa, pelo que há de inconsciente nessa pressa, Descartes decidiu por antecipação "eu" e "penso" como propriamente pensar, sem perscrutar ou comparar se “o que está acontecendo não seria talvez 'sentir' ou "querer" (JGB/BM 54, KSA 5.73). Mas a comparação de um estado momentâneo com outros estados, como sugere Nietzsche, não é o forte de Descartes. A transposição do método geométrico para a filosofia, que para além da demanda de rigor revela-se um veículo para a pressa em dominar o mundo indefinidamente extenso, não o permitiria. ${ }^{4}$ Desse modo, se deu um passo no reconhecimento de sua própria perspectiva subjetiva, tendo assim de lançar mão da noção de conhecimento via representação, Descartes não foi coerente com essa "não imediaticidade". De pronto cedeu à simplicidade, à intromissão despercebida de uma visão de mundo antiga, na qual entre mundo e homem, sendo correlatos e interrefletidos, havia acessos diretos e imediatos.

4. Filosofia e geometria trabalham com graus diferentes de abstração, o que Descartes parece não ter observado. Daí a comparação entre ideias ser um "vício de origem" a impregnar a noção-critério de "ideias claras e distintas" (e observe-se aqui a conjugação de claras $e$ distintas). Essa comparação bem funcionaria para as verdades geométricas, quando a clareza de uma ideia não depende da comparação com outras que lhe estejam próximas. Ocorre que fora do domínio puramente abstrato, geométrico ou aritmético, as coisas não se dariam dessa maneira. Por exemplo, a percepção clara do branco só poderia ser distinta se comparada à de outro branco, e este a confirmaria, negaria ou relativizaria mediante comparação. 
Krieger, S.

\section{A inconsciência pela linguagem}

Além da moralidade a se imiscuir na irrefletida busca da verdade, bem como na cláusula sub-reptícia de um mundo previamente ordenado, garantido por um deus providencial, além da irrefletida pressa em se restaurar uma fixidez perdida, Descartes, como a filosofia que o sucedeu, teria se deixado levar por ainda outra ação inconsciente - a da própria linguagem. Nietzsche alega que se falseia a realidade efetiva quando se diz "o sujeito 'eu' é condição do predicado "penso" (JGB/BM 17, KSA 5.31), por se concluir segundo hábitos gramaticais: "pensar é uma atividade, toda atividade requer um agente, $\log _{0}-"$ (JGB/BM 17, KSA 5.31). Uma palavra, como "eu", como "isso" em "isso pensa" já sinaliza interpretação de um processo, que, se é um distanciamento do próprio processo, como Nietzsche ali observa, é também um momento de irreflexão, pois introduz-se uma palavra, um conceito para naquele ponto não mais se pensar. Não seria tão grande problema se com o "deixar de pensar" tudo automaticamente estancasse no pensamento, tanto mais em se tendo um mundo prévia e moralmente ordenado, como é o de Descartes. Mas tal não ocorre, e pressupô-lo só seria mesmo possível a um pensamento mal concebido, mal discernido e mal comparado, assim tornado substância (Nachlass/FP 40 [22], agosto-setembro de 1885, KSA 11.639) - tal é, segundo Nietzsche, o pensamento cartesiano. Para o filósofo alemão, um pensamento não será uma massa substancializada de maneira inequívoca, mas será coetâneo, isto sim, a um sentir e a um querer, a muitos sentires, a muitos quereres que não são ordenados num substrato pensante, nem por ele hierarquizados, mas estão disseminados pelo corpo. Destes, nem todos são devidamente reconhecidos ou formulados, nem todos chegam à consciência. Mas por certo estão atuando sobre ela, mesmo quando ela se aparta do movimento reflexivo, introduzindo aí a moralidade reinante, a crença na palavra e na gramática, a cunhagem do conceito, seus pequenos e grandes pontos de fixidez.

236 | Cad. Nietzsche, Guarulhos/Porto Seguro, v.39, n.3, p. 223-245, setembro/dezembro, 2018. 
Um olhar de Nietzsche ao século XVII: os subterrâneos da revolução....

\section{O cogito como alma desnaturada}

Água para o moinho da ciência moderna: o enfeitiçamento pela linguagem fez com que Descartes transpusesse para ela a estupefação do homem ante a revolução científica dos séculos XVI-XVII: o mundo vem antes do homem, que ali não tem a centralidade nem a dignidade que até então se lhe atribuía. Paralelamente às dúvidas todas de um mundo muito mais amplo, tanto mais complexo e mais incerto, "tentou-se, então, com tenacidade e astúcia dignas de admiração, enxergar uma saída nessa teia - se não seria verdadeiro talvez o contrário: 'penso', condição; 'eu', condicionado"; "eu" sendo uma síntese, feita pelo próprio pensar" (JGB/BM 54, KSA 5.73). Para Nietzsche, feito nada desprezível de Descartes - adotado pela filosofia moderna, mesmo pela corrente empirista, intensificado sobretudo por Kant - foi atentar contra o antigo conceito de alma:

Pois antigamente se acreditava na "alma", assim como se acreditava na gramática e no sujeito gramatical: dizia-se que "eu' é condição, "penso" é predicado e condicionado - pensar é uma atividade para a qual um sujeito tem de ser pensado como causa (JGB/BM 54, KSA 5.73).

Tem-se aí o arcabouço que permeou todo o ato de conhecer e filosofar de até então, responsável pelas querelas infindáveis da Escolástica, cujo inteiro esquema foi rechaçado pela dúvida metódica e hiperbólica de Descartes: "alma", "eu" fizeram-se entidades de pronto varridas pela dúvida. O caminho que levou da dúvida ao "ponto fixo e seguro" não se ancorou primordialmente nem em alma nem em sujeito, mas reconheceu os pensamentos que se tinha ao duvidar: "'penso', condição; 'eu', condicionado; 'eu' sendo uma síntese, feita pelo próprio pensar” (JGB/BM 54, KSA 5.73). Desse modo, o que Nietzsche refere por "ceticismo epistemológico" de Descartes tornou secundário e condicionado o que a filosofia de até então postulava como princípio, como alma. Ocorre que o lugar da 
Krieger, S.

alma será de pronto ocupado pelo próprio cogito, que assim se faz uma alma desnaturada, refém da atividade primeira e inquestionável, que é o pensar, como também se fará refém das resultantes científicas dessa atividade.

Como estamos a ressaltar, em Nietzsche trata-se de desvelar a movimentação inconsciente por sob as resoluções cartesianas e fazer ver o seu alcance, no próprio Descartes e para além dele. Resta fazer ver que, ao em tal medida se pautar por ações inconscientes, podese não apenas ser homem de seu tempo, mas ir além, sucumbindo a ele. Tudo se passa como se, na intenção de encontrar para o homem um porto seguro em meio às intérminas disputas da Escolástica e diante do mundo tornado amplo e relativizador, ele uma vez mais inserisse esse homem - como incidência dos próprios pensamentos que o assaltam - como fator de segunda ordem, dependente de suas representações, e a elas subordinado. Note-se que falamos aqui em "uma vez mais". Esse "uma vez mais" refere-se bem a um ricocheteio do que se percebia à época, uma fidelidade a seu tempo, e entenda-se: em meio a um Universo do qual já não mais é o centro, e é indefinidamente extenso, Descartes replica essa condição ao subtrair a noção de alma (anima), com seus equívocos e conotações, preferindo a ideia de mente (mens). Porém esta seria efeito de um fluxo de pensamentos, fossem eles disparatados ou correspondentes ao que lhes apresenta a res extensa. Tudo se passa como se o "velho conceito de alma" (JGB/BM 54, KSA 5.73), agora como cogito, fosse novamente posto, mas tornado rarefeito e secundário, submetido ao "garrote" das representações que o assaltam. Um garrote que virá a progressivamente apertar um lugar ou "não lugar" no homem onde antes havia a sua alma. Garrote desencadeado, mas não sentido com desconforto num primeiro momento, o século XVII, que entendia-se como de otimismo e crença no poder da razão e de seus frutos.

238 Cad. Nietzsche, Guarulhos/Porto Seguro, v.39, n.3, p. 223-245, setembro/dezembro, 2018. 
Um olhar de Nietzsche ao século XVII: os subterrâneos da revolução....

\section{Uma certa herança cartesiana}

A esta altura é possível que já tenha ficado suficientemente claro o quanto as críticas de Nietzsche a Descartes não se esgotam no próprio Descartes, nem se movem na arena de seu racionalismo. Há menções aos séculos XVIII e XIX em sucessão ao XVII e mesmo em comparação a ele (Cf. Nachlass/FP 9 [178], outono de 1887, KSA 12.440). Há menção aos desdobramentos do que chamamos "garrote" e uma "desnaturação" da alma, justamente para os séculos seguintes - o lugar da alma é mantido, porém mais e mais atrofiado pelo seu "defeito de origem", ou seja, a dependência do pensamento e de seus feitos. Antes disso, porém, aqui salientamos a sua tentativa de uma rápida recuperação de um equilíbrio interno, psicológico e instintual, e fizemos referência a um "âmbito mais profundo" que o das admissões filosóficas.

Essas menções, a apontar para um "além" do próprio Descartes e do terreno cartesiano, foram assim deixadas como que esparsas. Se puderam parecer não levar a parte alguma, cumpre agora reunilas, explicitando aquele que seria o contexto mais amplo da crítica do autor do Zaratustra a Descartes. Para tanto, migre-se da esfera a que normalmente se atribui a hegemonia da atividade reflexiva e consciente e passe-se a outra, que de tão ampla vem a abarcála, e suscitá-la, como fez com a revolução cartesiana, desde seus subterrâneos. Pelo que se viu, a pretensa autonomia da razão, do pensamento que em si mesmo encontra as certezas e a via para o verdadeiro teve como maior preço o "atentado contra o velho conceito de alma" (JGB/BM 54, KSA 5.73). Por certo que para Nietzsche alma e seus correlatos e sucedâneos, como "sujeito", "eu", são meras ficções, como nessa direção ele também ressaltará o caráter ficcional de razão, pensamento e consciência (cf. Nachlass/FP 14 [122], primavera de 1888, KSA 13.301). Mas nem isso, nem mesmo a crítica à "necessidade atomista", a redundar num "atomismo da alma" 
Krieger, S.

(JGB/BM 12, KSA 5.26), impede-o de, num mesmo movimento textual, afirmar: "está aberto o caminho para novas versões e refinamentos da hipótese da alma" (JGB/BM 12, KSA 5.26). Por certo que essas novas versões não preveem um restauro daquele princípio que fora solapado desde Descartes, e sim, pelo contrário, deve bem nos conduzir ao plano das afirmações possivelmente esparsas que acima referimos.

Sempre decomponível, provisória, mortal, a alma segundo a hipótese de Nietzsche, refere-se justamente a algo de uma esfera que a filosofia desde sempre evitou, algo da animalidade em nós - os seres vivos microscópicos a formar o corpo: "Nosso corpo nada mais é do que um edifício coletivo de várias almas" (JGB/BM 19, KSA 5.31). Mas deve-se atentar ao fato de que para "alma" o filósofo não vai conferir o estatuto de uma designação exclusiva e excludente. Não se trata de "uma célula, uma alma", "uma organela, uma alma", ou algo assim. Se não há essência una, estável e bem delimitada, tampouco ele a vai denotar por uma notação unívoca. Aos referidos seres microscópicos, se a depender do contexto Nietzsche os refere por "almas", em outras ocasiões os designa por "consciências" [Bewußtseins $][. .$.$] que a todo instante constituem sua existência e seu$ corpo" (Nachlass/FP 37 [4], junho-julho de 1885, KSA 11.576). E uma vez que há uma variável processualidade, e não estabilidade a subjazer aos pretensos referentes, no mesmo sentido se terá instintos [Instinkte $]^{5}$ a tiranizar a consciência, como no aforismo 11 d'A gaia

5 Embora Nietzsche se utilize dos termos "instintos" [Instinkte] e "impulsos" [Triebe] não raro de modo intercambiável e indiscernível, em alguns momentos, como no primeiro aforismo d’A gaia ciência, pode-se depreender a ideia de um instinto de conservação da espécie sendo composto por aglomerados de impulsos, que, bem entendido, devem ser tomados não como coisas, mas ao modo de processos sempre decomponíveis. Um critério possível para diferenciar "instintos" de "impulsos" seria a questão da memória, pela qual instintos seriam grupos de impulsos em que se cristalizou um modo de interagir com o meio que os cerca.

$240 \mid$ Cad. Nietzsche, Guarulhos/Porto Seguro, v.39, n.3, p. 223-245, setembro/dezembro, 2018. 
Um olhar de Nietzsche ao século XVII: os subterrâneos da revolução....

ciência, e também "impulsos" $[\text { Triebe }]^{6}$, "forças" $[\text { Kräft }]^{7}$, "afetos" [Affekte], ou também "vontades" [Wille]. ${ }^{8}$ Uma vez que não incorre na pedra de tropeço da moralidade inconsciente, nem na das malhas da gramática, Nietzsche não se permite crer numa objetividade estabelecida ou na unicidade de um referente a que corresponderia o termo "alma". "Alma" assim lhe é mero dispositivo linguístico, acionado ao sabor da trama textual. Uma vez que não sucumbe à ação de uma certa moralidade inconsciente, tampouco se dá a hierarquizações e separações irrefletidas, como a que apartaria da pretensa alma - que antes era um conceito moral e filosoficamente "nobre" - um sempre possível agregado de outras almas, e do seio desta a capacidade de perceber, de sentir, de desejar e se atrair ou sentir aversões, de ser, afinal, uma inextinguível e incontornável configuração de vontades.

A substituir a antiga e cristã hipótese de alma e a restituir a insipidez do cogito então se apresentam impulsos orgânicos, afetos

6 Os impulsos são o modo pelo qual a vontade de potência se expressa nos organismos vivos, fazendose presente no âmago de seus processos por disposições como (1) o empuxo para descarregar força armazenada; (2) a necessária interação entre eles - pois só como abstração podem ser pensados como unidades -; (3) seu aspecto axiológico - pois a todo tempo os impulsos se intervaloram, e a valoração pauta o modo como interagem entre si. Embora se oponham à consciência e à razão, protagonizando a esfera "subterrânea" que aqui se está a sugerir e tematizar, essa oposição não possui caráter terminante ou absoluto, e sim de grau, já que os processos de interação pulsional demandam rudimentos de razão e uma atitude desperta (a ponto de serem referidos por "consciências" no fragmento 37 [4], junho-julho de 1885, KSA 11.576) e de uma racionalidade. Dessa racionalidade por assim dizer "pulsional", que se dá pela ação de buscar algumas interações, esquivando-se a outras, a razão tal qual a conhecemos vem a ser um desdobramento que se fez possível mediante o engendramento da linguagem articulada.

70 conceito de força de Nietzsche não é o conceito científico de força, a cuja insipidez, aliás, proporá o complemento da "dimensão interior", do "apetite insaciável" a que chamará "vontade de potência" (Nachlass/FP 36 [31], junho-julho de 1885, KSA 11.563). Se tal como os impulsos, as forças são uma expressão particular de vontade de potência, deles se distinguirian pelo realce que se dá ao "idioma" por meio do qual se instaura entre os impulsos a necessária comunicação no âmbito da psicologia do comando: "a única força que existe é de mesma natureza que a da vontade: uma ordem dada a outros sujeitos e segundo a qual eles se transformam (Nachlass/FP 40 [42], agosto-setembro de 1885, KSA 11.650).

8 Sobre a nova língua de Nietzsche, e seu modo de se colocar em meio a uma realidade que é processual, cf. C. Denat, \& P. Wotling. 2013, p. 7-21, em especial p. 15-16.

Cad. Nietzsche, Guarulhos/Porto Seguro, v.39, n.3, p. 223-245, setembro/dezembro, 2018. 
Krieger, S.

ou vontades, dos quais não está excluída uma reflexividade e uma linguagem a pautar as interações entre eles. ${ }^{9}$ Entre eles há um embate constante em cujo seio se dá o equilíbrio orgânico, e eventualmente um desequilíbrio a afetar o "conservador vínculo dos instintos" (FW/ GC 11, KSA 3.382). Se o homem é no fundo instintual, no animalhomem desequilíbrios orgânicos têm consequências psicológicas e intelectuais profundas. Podem ser ocasionados pela perda de uma inteira visão de mundo, como se teve com o animal-homem, por ocasião da revolução científica, suscitando respostas não apenas intelectuais, mas de profundidade psicológica, como se teve com resposta cartesiana. A resposta tende a apontar para uma outra ordem, de viés epistemológico, para um outro sistema, no qual o equilíbrio talvez, e por algum tempo, possa se restaurar. Muito antes de Descartes, foi por um desequilíbrio a ameaçar a inteira espécie do homem ainda animal que se constituiu a linguagem articulada (cf. FW/GC 354, KSA 3.590). E pelo engendramento da linguagem verbal, a reflexividade vigente no organismo se duplica, constituindo a consciência tal qual a conhecemos. ${ }^{10}$ Esta, assim como as "almas" propostas por Nietzsche a subjazê-la, doravante pode se valer de um lastro de fisiológica vitalidade, sem necessariamente estar sujeita ao referido "garrote" do cogito cartesiano. Quando a ele sujeito, em função de um pensamento pretensamente rigoroso, os frutos desse pensamento cercaram o homem de avanços e feitos voltados a lhe aumentar os prazeres e a diminuir a dor (cf. FW/GC 12, KSA 3.383),

9 A esse respeito, cf. P. Wotling, 2011; J. Constâncio, 2011. Sobre o aprofundamento da compreensão por Nietzsche das interações pulsionais ao longo das pesquisas que realizou o longo da década de 1880, cf. Müller-Lauter., W. 1978.

10 A consciência tal qual a conhecemos é para Nietzsche apenas um tornar consciente de um pensamento que já existe na esfera pulsional, e o pensamento assim se torna consciente por ocorrer em palavras. Em outras palavras, a consciência é engendrada no ser humano por meio da duplicação de uma reflexividade já organicamente atuante, disseminada por todo o corpo. Como mera "rede de ligação entre homem e homem", ela advém por "um longo "é preciso", pela necessidade de "saber como se sente, de saber como "se pensa"” (cf. FW/GC 354, KSA 3.590).

242 | Cad. Nietzsche, Guarulhos/Porto Seguro, v.39, n.3, p. 223-245, setembro/dezembro, 2018. 
Um olhar de Nietzsche ao século XVII: os subterrâneos da revolução....

mas sem o reconduzir à dignidade de que dispunha no período prérevolução científica. Perdendo até mesmo o acesso às coisas, sem nem mesmo poder ser pensado por si mesmo, ao longo dos séculos XVIII e XIX o homem desnaturado de si fez-se mais e mais desvitalizado, a desvalorizar valores, negar a vontade, a ponto de intensamente se identificar a Schopenhauer na segunda metade do século XIX. Porque empenhara suas vontades a ídolos de pés de barro, com a derrocada destes, a sucessivos golpes de conhecimento, pôs a perder as próprias vontades, sua capacidade de desejar. Para Nietzsche, a esse inteiro quadro a altivez da revolução cartesiana deu sua mais valiosa contribuição.

\begin{abstract}
This article has the purpose to highlight how does the "cartesian revolution" reveals itself to Nietzsche as a thoughtless answer to unconscious devices. Thus, the alleged radicality in the foundation of his philosophy and its unfolding would have happened by the intrusion of the following unconscious agents: the yearning of a physio-psychological accommodation behind the cogito; the unconscious morality ranking the intellect as higher than the sensible and the passional spheres, as well as implying a well-ordered world, obedient to the clear and distincts ideas; a third factor of uncouscious agency would be the habits of grammar, whereby he proceeds just in inverting the primacy between "I" and "think", providing thought and its scientific deeds with a "tourniquet action" exerted on the ancient notion of soul. This framework continued to worsen until the second half of nineteenth century, when Nietzsche discovered philosophy.
\end{abstract}

Key-words: Descartes, psychology, physiology, moral, drives, soul. 
Krieger, S.

\section{Referências bibliográficas:}

CHAUÍ, M. "Um anacronismo interessante”. In: MARTINS, A., SANTIAGO, H. \& OLIVA, L. C. As ilusões do eu. Rio de Janeiro: Civilização Brasileira, 2011.

CONSTÂNCIO, J. "Instinct and Language in Beyond Good and Evil". In: CONSTÂNCIO, J. \& BRANCO, M. J. M. (org.) Nietzsche on Instinct and Language. Berlin/Boston: De Gruyter, 2011

DENAT, C. WOTLING, P. Dictionnaire Nietzsche. Paris: Ellipses, 2013.

DESCARTES, R. As paixões da alma. In: Descartes, coleção "Os pensadores". Trad. J. Guinsburg e Bento Prato Júnior. São Paulo: Abril Cultural, 1979.

Discurso do método. Trad. J. Guinsburg e Bento Prato Júnior. In: Descartes, coleção “Os pensadores”. São Paulo: Abril Cultural, 1979.

. Meditações metafísicas. Trad. J. Guinsburg e Bento Prato Júnior. In: Descartes, coleção “Os pensadores”. São Paulo: Abril Cultural, 1979.

. Princípios de filosofia. Trad. Heloísa Burati. São Paulo: Rideel, 2005.

KOYRÉ, A. Do mundo fechado ao universo infinito. Trad. Jorge Pires. Lisboa: Gradiva, 1961.

MARTON, S. "Contra modernos e pós-modernos: Nietzsche e as filosofias de fachada". In: MARTINS, A., SANTIAGO, H. \& OLIVA, L. C. As ilusões do eu. Rio de Janeiro: Civilização Brasileira, 2011.

. "Nietzsche: Consciência e inconsciente". In: MARTON, S. Extravagâncias. Ensaios sobre a filosofia de Nietzsche. São Paulo: Discurso Editorial/Barcarolla, 2009.

. "Nietzsche e Descartes: filosofias de Epitáfio". In: MARTON, S. Extravagâncias. Ensaios sobre a filosofia de Nietzsche. São Paulo: Discurso Editorial/Barcarolla, 2009.

MÜLLER-LAUTER., W. “Der Organismus als innerer Kamp. Der Einfluß von Wilhelm Roux auf Friedrich Nietzsche”. In: Nietzsche-Studien 7, 1978, p. 189-223.

NIETZSCHE, F. Sämtliche Werke. Kritische Studienausgabe. Berlin/New York : Walter de Gruyter, 1999.

244 | Cad. Nietzsche, Guarulhos/Porto Seguro, v.39, n.3, p. 223-245, setembro/dezembro, 2018. 
Um olhar de Nietzsche ao século XVII: os subterrâneos da revolução....

. Obras incompletas, coleção "Os pensadores". Trad. Rubens Rodrigues Torres Filho. São Paulo: Abril Cultural, 1978.

. Para além de bem e mal. Trad. Paulo Cézar Souza. São Paulo : Companhia das Letras, 1992.

WOTLING, P. “What Language do Drivesspeak?”. In: CONSTÂNCIO, J. \& BRANCO, M. J. M. (org.) Nietzsche on Instinct and Language. Berlin/Boston: De Gruyter, 2011.

Artigo recebido para publicação em 15/03/2018 Artigo aceito para publicação em 18/06/2018 